\title{
The next common and widespread bunting to go? Global population decline in the Rustic Bunting Emberiza rustica
}

\author{
LARS EDENIUS, CHANG-YONG CHOI, WIELAND HEIM, \\ TUOMO JAAKKONEN, ADRIAAN DE JONG, KIYOAKI OZAKI and \\ JEAN-MICHEL ROBERGE
}

\section{Summary}

Populations of several long-distance migratory songbirds in Eurasia are in peril, drastically illustrated by the recent range-wide population collapse in the Yellow-breasted Bunting Emberiza aureola. There are signals of a strong decline also in the Rustic Bunting E. rustica, but no range-wide assessment of population trends in this superabundant and widespread bunting species has yet been undertaken. The conservation status of Rustic Bunting is 'Least Concern' on the global IUCN Red List, but it has recently been upgraded to 'Vulnerable' on the European Red List. To assess the Rustic Bunting's global conservation status we compiled, for the first time, population data across its breeding and wintering ranges. The analysis reveals a $75-87 \%$ decline in overall population size over the last 30 years and a $32-91 \%$ decline over the last 10 years. The trend estimates indicate that the long-term (30-year) range-wide population decline in the Rustic Bunting is of similar magnitude to two well-known examples of declining species within the same genus, the Yellow-breasted Bunting and the Ortolan Bunting E. hortulana. The magnitude of the range-wide population decline over the last 1o years suggests that the Rustic Bunting could be upgraded from 'Least Concern' to 'Vulnerable' or 'Endangered' on the IUCN global Red List. Agricultural intensification in the wintering range and intensified levels of disturbance, including logging and fire, in the breeding range could be important drivers of the range-wide population decline, and persecution could also contribute. Untangling threat factors and their interactions on Rustic Bunting is necessary for conservation, but hampered by our currently limited understanding of the relationships between population dynamics and different threats.

\section{Introduction}

A large number of long-distance migratory songbirds exhibit decreasing population trends in Eurasia (Sanderson et al. 2006, Laaksonen and Lehikoinen 2013, Vickery et al. 2014). Amongst the 170 long-distance migratory songbird species using the East Asian flyway, for example, one third show declining trends and $12 \%$ are classified as threatened or near-threatened (Yong et al. 2015). Whilst the drivers of population declines are comparatively well studied in the AfroPalearctic migratory system (Vickery et al. 2014), such knowledge is scarce for the East Asian flyway (Yong et al. 2015). Asia has seen a strong intensification in agriculture during recent decades, and witnessed increasing urbanisation and industrialisation (Alauddin and Quiggin 2008). Anthropogenic and climate-related stressors in the form of logging, draining, and forest fires have also increased (Goldammer and Furyaev 1996, Achard et al. 2006) as has trapping of songbirds 
for consumption and religious merit release (Gilbert et al. 2012, Townsend 2015, Yong et al. 2015). Stronger environmental pressures on breeding and wintering habitats and increased levels of persecution have therefore emerged as serious threats to long-distance migratory songbird populations in East Asia.

Habitat loss and persecution are considered as threats to rare and range-restricted species, but the scale of these factors may now have reached levels whereby even superabundant and wide-ranging species are becoming threatened. For example, data for Yellow-breasted Bunting Emberiza aureola, compiled across its distribution in Eurasia, showed that the global population of this once very abundant species, virtually collapsed over a time period of only 25 years (Kamp et al. 2015). The Rustic Bunting Emberiza rustica shares many ecological traits with the Yellow-breasted Bunting. For example, both have very large and almost overlapping breeding ranges, being superabundant long-distance migrants, and use similar migration routes (Byers et al. 2013). There are some signals of a strong population decline also in the Rustic Bunting (BirdLife International 2015a), but the details and causes of the decline remain unclear.

The distribution of the Rustic Bunting spans roughly 170 degrees of longitude, across Eurasia from Fennoscandia in the west to the Kamchatka peninsula in the east (Cramp and Perrins 1994). The breeding range, which is estimated at $218 \mathrm{Mha}$ (BirdLife International 2015a), is intimately linked to the boreal forest, wherein the typical breeding habitat is wet coniferous forest with birch Betula spp. and willow Salix spp. growth along slow-flowing water (Öhrn 1963, Pulliainen and Saari 1989, Kretchmar 2000). Current evidence suggests that the winter range of the Rustic Bunting is confined to East Asia comprising Japan, the Korean Peninsula, and eastern and central mainland China north of the tropic of Cancer (Byers et al. 2013). For the bulk of the population, autumn migration follows forested regions eastwards, turning south in Asia east of Mongolia (Cramp and Perrins 1994, Byers et al. 2013). While just a few birds migrate through or winter in Kazakhstan (Berezovikov and Levinskiy 2008), the Rustic Bunting is one of the most common species during migration in the Russian Far East (Averin et al. 2012, Heim et al. 2012, Heim and Smirenski 2013). Birds from Kamchatka (sometimes regarded as a separate subspecies latifascia) are believed to migrate south-west across the Sea of Okhotsk or south to Japan across the Sea of Japan (Valchuk et al. 2005). The spring migration in the Rustic Bunting appears to mirror the autumn migration, but the details of its migratory patterns including stopover sites are inadequately known.

During the breeding season, the diet of Rustic Bunting mostly consists of invertebrates, whereas it shifts to seeds, grasses, and other vegetable food in other seasons (Cramp and Perrins 1994). A variety of semi-open habitats are used during stopovers and in the winter range, including woodlands, willow thickets, clearings, rice stubble, reed beds and riverbanks (Cramp and Perrins 1994, Fujioka et al. 2010, Yoo et al. 2011, Schäfer et al. in prep). At its winter feeding sites, the Rustic Bunting prefers wet grassy places with plenty of seeds and presence of dense shrubs or trees (Iijima 1973, Maeda 2001). Maeda (1973) observed spatially segregated habitat use in the Rustic Bunting during winter, with flocks of several hundred birds feeding in rice paddies during daytime and roosting in loosely dispersed groups in shrubby or grassy patches in woodland areas up to $\mathrm{I} \mathrm{km}$ from the feeding sites.

The Rustic Bunting is classified as a species of 'Least Concern' (LC) on the IUCN Red List, i.e. it is not considered globally threatened (BirdlLife International 2012). However, it has recently been upgraded to 'Vulnerable' (VU) on the European Red List (BirdLife International 2015b). Population trends have been estimated for Fennoscandia (Dale and Hansen 2013) and Europe (BirdLife International 2015a) but not for the whole distribution range. Trend assessments and expert opinions suggest that the European breeding population of Rustic Bunting has declined by $30-49 \%$ over the last 10 years in Europe, but only around one-fifth of the species' global breeding range is within Europe (Symes 2015). For large parts of the breeding range, population trends remain unknown. While earlier population assessments have focused on restricted parts of the distribution range and included a limited amount of time series data, we here present the first 
range-wide assessment of population trends in the Rustic Bunting based on several short and long term time series.

We compiled Rustic Bunting data from different countries to determine the range-wide rates of population change and hence assess the species's global status. We also present an overview of possible drivers underlying the decline and propose key research activities to help overcome the current lack of knowledge about the bunting's ecology which hampers effective conservation policies.

\section{Material and methods}

\section{Data collection}

We collated time series data on the Rustic Bunting from countries in the breeding range (Norway, Sweden and Finland) and from stop-over sites during migration (Japan and north-eastern China). Standardised breeding survey data were preferentially used, but since such data are scarce we also included ringing data. In case of ringing data we only included standardised time series data, i.e. data controlled for capture effort. We used nationwide breeding survey data from Sweden and Finland and breeding territory count data for the very small Norwegian population (Green and Lindström 2015a, Hansen 2015, Aleksi Lehikoinen pers. comm.). In Sweden, breeding survey counts have been carried out on fixed routes systematically distributed across Sweden since 1998 (Green and Lindström 2015a). However, the number of surveyed fixed routes within the Rustic Bunting's breeding range in northern Sweden was low during the first years. Therefore, we used Swedish breeding bird data only from the last 1o years (2005-2014). To increase the length of the overall time series we complemented the Swedish breeding survey data with Rustic Bunting data from ringing stations. The Japanese and Chinese data consisted of the number of Rustic Buntings ringed during autumn migration at ringing stations. In total, we compiled seven time series of data of up to 30 years in length, see Table $I$ and Appendix $S_{I}$ in the online supplementary materials for details.

\section{Statistical analysis}

For the Swedish and Finnish breeding bird survey data, we used TRIM-estimated (Pannekoek and van Strien 2013) yearly population indices and linear trends provided to us by the national programme organisers. To make the ringing data comparable with these breeding survey data, we also used TRIM (ver. 3.54) to calculate indices and trends. In the case of the Norwegian breeding survey data we applied TRIM to the numbers of occupied territories 2008-2014 (Hansen 2015; Table 1 , Figure $1 \mathrm{~b}$ ). The widespread TRIM (TRends and Indices for Monitoring data) software uses log-linear models with a Poisson error distribution and allows for missing counts. Yearly population indices were scaled (indexed) to 1 for the starting year. We employed models that controlled for over-dispersion and serial correlation, and used trend estimates based on the imputed population indices (to account for missing values) as recommended by Pannekoek

Table 1. TRIM-estimated annual decline rates for national data sets 1985-2014. P-levels denote significance of deviation of slope values from I (= no change).

\begin{tabular}{llll}
\hline Country & Time period & Annual change, $\%$ & $P$-level \\
\hline Norway & $2005-2014$ & -30 & $<0.05$ \\
Sweden & $1985-2014$ & -6.0 & $<0.01$ \\
Sweden & $2005-2014$ & -5.3 & $<0.001$ \\
Finland & $1985-2014$ & -6.1 & $<0.001$ \\
Japan & $1985-2014$ & -4.5 & $<0.01$ \\
China & $2005-2014$ & -20 & $<0.05$ \\
\hline
\end{tabular}


a) Long-term (1985-2014)

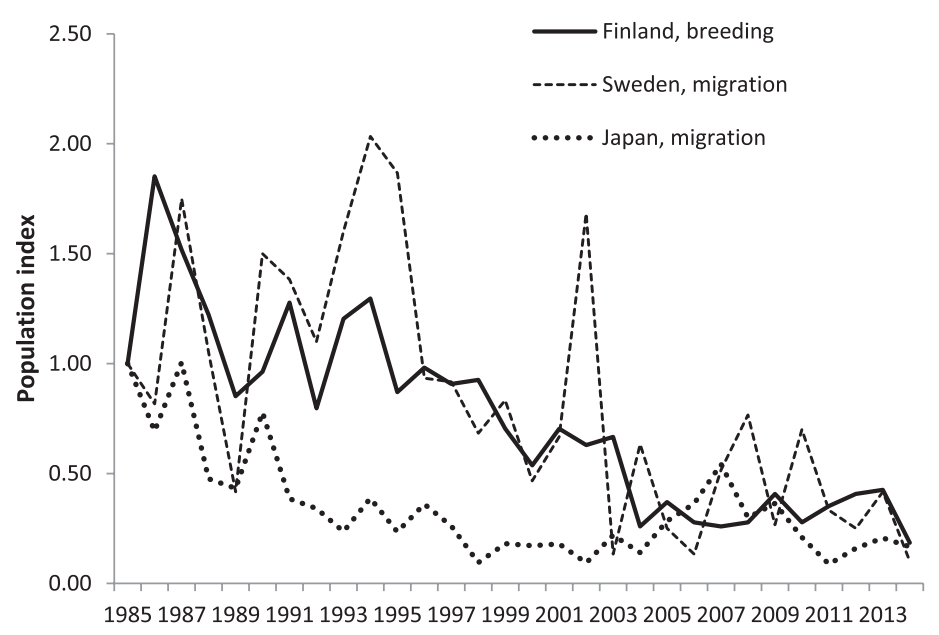

b) Short-term (2005-2014)

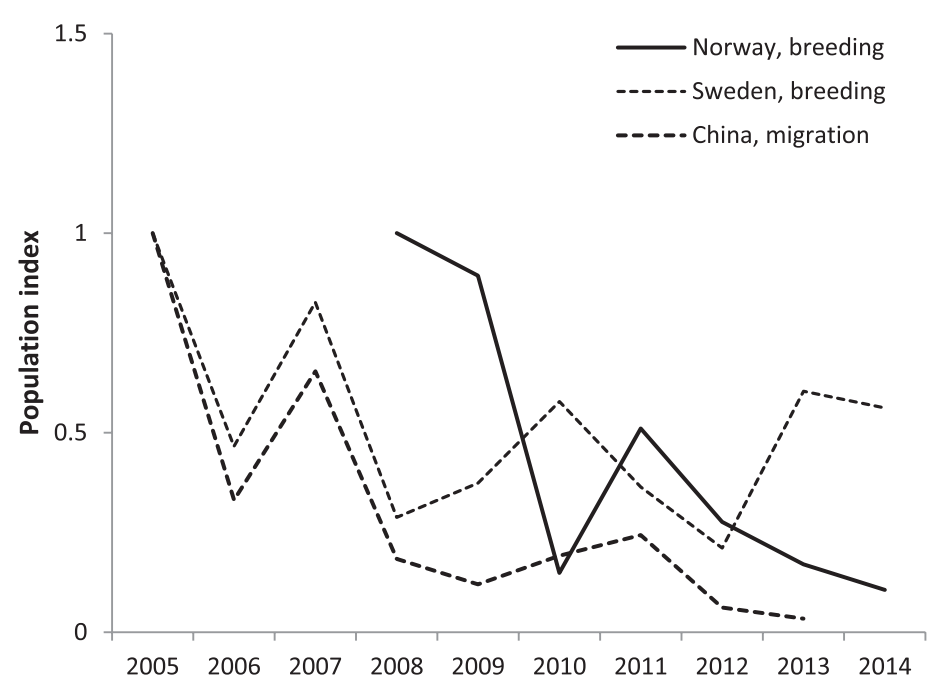

Figure 1. TRIM estimated yearly indices of Rustic Bunting numbers in long-term (a) and short-term (b) data series.

and van Strien (2013). Rangewide trends were estimated by averaging the national time-series trends. Trends were estimated for 30 years (1985-2014, long-term) and 10 years (2005-2014, short-term), respectively. Missing values amounted to $2 \%(n=2)$ and $7 \%(n=5)$ of the data points in the long- and short-term datasets, respectively. The small population in Norway, where the Rustic Bunting is dwindling and is estimated currently at less than 1o pairs (Hansen 2015), may have a disproportionate impact on the range-wide trend estimates. Therefore, we analysed the time-series data also without the Norwegian data. 


\section{Results}

The TRIM-estimated yearly indices of the national data series revealed consistent population declines across the range (Table 1, Figure 1). For the long-term data $(1985-2014)$, the average range-wide annual decline rate was estimated at 5.5\% ( $\pm 1.0 \% 95 \% \mathrm{CI})$, which corresponds to an $82 \%(75-87 \%)$ reduction in population size over 30 years. The short-term (2005-2014) annual decline rate was $12.4 \%( \pm 8.6 \% 95 \% \mathrm{CI})$, corresponding to a $73 \%(32-91 \%)$ reduction over 10 years (Figure $\mathrm{ib}$ ). When we re-ran the analyses after excluding the Norwegian data, it yielded a 1o-year annual decline rate of $8.9 \%( \pm 6.3 \% 95 \% \mathrm{CI})$, i.e. a $60 \%(23-81 \%)$ overall decline.

\section{Discussion}

Our analysis provides compelling evidence for a strong range-wide decline in Rustic Bunting populations in recent times. To put the magnitude of the population decline into perspective, we can compare it with two better-known examples of dramatic range-wide population declines within the same genus: the Yellow-breasted Bunting and the Ortolan Bunting E. hortulana. The decline in the Yellow-breasted Bunting was estimated at $84-95 \%$ over 34 years (Kamp et al. 2015). An extrapolation of our $82 \%(75-87 \%)$ long-term (30 year) trend in the Rustic Bunting yields an $85 \%$ rangewide decline over 34 years. For the Ortolan Bunting, Vickery et al. (2014) reported an 84\% decline over 30 years (1980-2009), which was the strongest population decline of all long-distance migratory species in the Afro-Palearctic migratory system they studied. In the case of the Yellow-breasted Bunting, the population collapse was accompanied by a strong eastward range contraction. Although such a dramatic global range contraction has not yet been observed in the Rustic Bunting, the range contraction towards north-east within Fennoscandia has been dramatic. On the western edge of the global distribution huge areas of habitat on the former Rustic Bunting distribution are now more or less empty of the species (Valkama et al. 2011, Dale and Hansen 2013, Green and Lindström 2015b).

The decline rate estimates have strong relevance for the ongoing discussion about the conservation status of the Rustic Bunting on the IUCN global Red List where it is currently listed in the 'Least Concern' (LC) category. Our range-wide estimate of a 61\% (73\% with the Norwegian data) population decline for 2005-2014 (a time span roughly corresponding to three generations in the Rustic Bunting; Symes 2015) indicates a decline well over the 30\% threshold required for classification as 'Vulnerable' (VU). Moreover, the observed population reduction exceeds the $50 \%$ threshold for the category 'Endangered' (EN) on the global Red List.

Our data samples are biased towards Fennoscandia. This is an unavoidable consequence of the fact that more data series are available from that part of the distribution range. From Russia, which holds the bulk of the breeding population, we found only scattered information on breeding densities (e.g. Rogacheva 1992 - Central Siberia, Kretchmar 2000 - noth-east Siberia), but no standardised data on long-term population development. However, numbers of Rustic Buntings captured during standardised ringing at Muraviovka Park in the Amur region of Russia show a decrease of $>90 \%$ in recent years (2012-2015) (Wieland Heim pers. obs.). The Gaofeng Bird Ringing Station located on the Chinese side of the Amur River also reports a strong recent decline (Table 1 , Figure $1 \mathrm{~b}$ ). This suggests that the decline in numbers of Rustic Buntings passing through this part of East Asia during migration has been particularly strong. The negative trend expressed by the Fukushimagata Ringing Station data in Japan (Figure 1a) is also seen in the non-standardised national ringing sums of Rustic Bunting in that country for the same time period (Kiyoaki Ozaki pers. obs.). In South Korea no long-term standardised data series exist, but non-standardised short-term ringing data show that capture rates of Rustic Bunting (measured as the proportion of total ringing sums) are now about 1o times lower than they were in the mid-1960s (Chang-Yong Choi pers. obs.). Also in China there is a shortage of standardised ringing data (Bo Pettersson pers. comm.). We included the most comprehensive data series from China, from the Gaofeng Bird Ringing Station, Heilongjiang Province (Appendix $\mathrm{S}_{1}$ ) in our analysis, and it showed a strong decline in number of Rustic Buntings over the last 10 years (Table 1 , Figure 1 b). To conclude, both 
Table 2. Changes in land use practices, natural processes and persecution, and their potential impacts on Rustic Bunting populations.

\begin{tabular}{|c|c|c|c|c|}
\hline Practice/process & $\begin{array}{l}\text { Effect on Rustic Bunting } \\
\text { habitat or populations }\end{array}$ & $\begin{array}{l}\text { Estimated } \\
\text { strength of } \\
\text { impact }\end{array}$ & Trend & Reference \\
\hline \multicolumn{5}{|l|}{ Breeding range } \\
\hline $\begin{array}{l}\text { Draining to } \\
\text { enhance forest } \\
\text { productivity }\end{array}$ & $\begin{array}{l}\text { Habitat loss/degradation. } \\
\text { Decreasing in the western } \\
\text { range but may be increasing } \\
\text { elsewhere }\end{array}$ & Moderate & Increasing? & $\begin{array}{l}\text { Skogsstyrelsen } \\
\text { (2014), Metla } \\
\text { (2015) }\end{array}$ \\
\hline Forest logging & $\begin{array}{l}\text { Habitat loss. Increasing intensity } \\
\text { in parts of the range }\end{array}$ & $\begin{array}{l}\text { Moderate- } \\
\text { strong }\end{array}$ & Increasing & $\begin{array}{l}\text { Skogsstyrelsen } \\
\text { (2014), Achard } \\
\text { et al. (2006) }\end{array}$ \\
\hline Wild fires & $\begin{array}{l}\text { Habitat loss. Increasing, } \\
\text { particularly in central and } \\
\text { eastern parts in response to } \\
\text { climate change and increased } \\
\text { anthropogenic disturbance }\end{array}$ & Strong & Increasing & $\begin{array}{l}\text { Achard et al. } \\
\text { (2006), } \\
\text { Flannigan et al. } \\
\text { (2009) }\end{array}$ \\
\hline $\begin{array}{l}\text { Melting/ } \\
\text { retreating } \\
\text { permafrost }\end{array}$ & $\begin{array}{l}\text { Habitat loss/degradation. Drying } \\
\text { up of wet forests related to } \\
\text { climate change. Large areas } \\
\text { in the eastern range potentially } \\
\text { affected }\end{array}$ & Strong & Increasing & Soja et al. (2007) \\
\hline $\begin{array}{l}\text { Dam } \\
\text { constructions }\end{array}$ & $\begin{array}{l}\text { Habitat loss. Central and eastern } \\
\text { parts of the range }\end{array}$ & Moderate & Unknown & $\begin{array}{l}\text { Achard et al. } \\
\qquad(2006)\end{array}$ \\
\hline \multicolumn{5}{|l|}{ Wintering range } \\
\hline Use of pesticides & $\begin{array}{l}\text { Reduced food resources, potential } \\
\text { poisoning. High application } \\
\text { rates in China, Japan and the } \\
\text { Republic of Korea }\end{array}$ & Strong & Increasing & $\begin{array}{l}\text { Bright et al. } \\
\quad(2008)\end{array}$ \\
\hline $\begin{array}{l}\text { Multiple crop } \\
\text { cycles }\end{array}$ & $\begin{array}{l}\text { Habitat loss and/or degradation } \\
\text { due to reduction in winter } \\
\text { stubbles which are important } \\
\text { feeding habitats }\end{array}$ & Strong & Increasing & $\begin{array}{l}\text { Round and } \\
\text { Gardner (2008) }\end{array}$ \\
\hline $\begin{array}{l}\text { Reduction } \\
\text { in grassland } \\
\text { area }\end{array}$ & $\begin{array}{l}\text { Habitat loss. Grasslands important } \\
\text { as feeding habitat. Significant } \\
\text { reduction in grassland area in } \\
\text { China } 1990-2000\end{array}$ & Strong & Increasing & $\begin{array}{l}\text { Maeda (2001), Shi } \\
\text { et al. (2012) }\end{array}$ \\
\hline $\begin{array}{l}\text { Changes in area } \\
\text { of fallow land }\end{array}$ & $\begin{array}{l}\text { Habitat loss/degradation when } \\
\text { fallow land becomes actively } \\
\text { managed, vice versa when use } \\
\text { ceases. Variable trends reported } \\
\text { across the range }\end{array}$ & Strong & Diverging & $\begin{array}{l}\text { Round and } \\
\text { Gardner (2008), } \\
\text { Amano (2009), } \\
\text { Long et al. } \\
\text { (2009) }\end{array}$ \\
\hline $\begin{array}{l}\text { Transformation of } \\
\text { farmland and } \\
\text { woody areas to } \\
\text { other land uses }\end{array}$ & $\begin{array}{l}\text { Habitat loss in case of urban and } \\
\text { rural settlement expansion, } \\
\text { potential habitat enrichment } \\
\text { after abandonment of } \\
\text { farmland }\end{array}$ & Strong & Diverging & $\begin{array}{l}\text { Long et al. (2009), } \\
\text { Wu et al. } \\
\text { (2009) }\end{array}$ \\
\hline $\begin{array}{l}\text { Planting of trees } \\
\text { and other } \\
\text { woody } \\
\text { vegetation }\end{array}$ & $\begin{array}{l}\text { Unknown; improved habitat } \\
\text { conditions due creation of } \\
\text { woody patches in rural } \\
\text { residential areas, but potential } \\
\text { habitat loss when food-rich } \\
\text { farmland is turned into } \\
\text { large-scale tree plantations }\end{array}$ & Moderate & Increasing? & Wu et al. (2009) \\
\hline
\end{tabular}


Table 2. Continued.

\begin{tabular}{clllc}
\hline Practice/process & $\begin{array}{l}\text { Effect on Rustic Bunting } \\
\text { habitat or populations }\end{array}$ & $\begin{array}{l}\text { Estimated } \\
\text { strength of } \\
\text { impact }\end{array}$ & Trend & Reference \\
\hline $\begin{array}{l}\text { Climate change } \\
\text { and unfavorable } \\
\text { weather } \\
\text { conditions }\end{array}$ & $\begin{array}{c}\text { Drought and lowered ground } \\
\text { water table; may change } \\
\text { vegetation structures in } \\
\text { natural grasslands and shrub } \\
\text { habitats }\end{array}$ & Moderate & Increasing & $\begin{array}{c}\text { Tamada et al. } \\
\text { (2014) }\end{array}$ \\
$\begin{array}{c}\text { Trapping for the } \\
\text { trade market, } \\
\text { private use or } \\
\text { merit release }\end{array}$ & $\begin{array}{c}\text { Communal roosting habits } \\
\text { increase susceptibility to } \\
\text { trapping }\end{array}$ & $\begin{array}{c}\text { Strong } \\
\text { (regionally) }\end{array}$ & $\begin{array}{c}\text { Persisting; } \\
\text { increasing? }\end{array}$ & $\begin{array}{c}\text { Maeda (1973), } \\
\text { Kamp et al. } \\
\text { (2015), Yong } \\
\text { et al. (2015) }\end{array}$ \\
\hline
\end{tabular}

available standardised data and anecdotal information give unequivocal support for a strong range-wide population decline in Rustic Bunting over the last decades.

\section{Possible drivers and knowledge gaps}

Little is known about the magnitude of the impact of different threat factors and their interactions with regard to the population decline of long-distance migratory songbirds in the East Asian Flyway (Yong et al. 2015). In Table 2 we have compiled threat factors related to changes in land use practices, natural processes and persecution that may affect population dynamics in the Rustic Bunting. To untangle the effects of different threats we need better data on population demographics. For example, using data modelling Kamp et al. (2015) concluded that an initial harvest rate of $2 \%$ followed by a $0.2 \%$ annual increase was sufficient to produce a population collapse in the Yellow-breasted Bunting over a time period of 34 years. Currently we do not know to what extent survival in the Rustic Bunting is affected by habitat change and persecution. Similarly, our knowledge about the effects of habitat change on Rustic Bunting productivity is limited. Poor nesting success coupled to habitat loss and degradation could be a population limiting factor, as has been suggested in case of Jankowski's Bunting E. jankowskii (Jiang et al. 2008).

Assessment of the impacts of different threat factors is also hampered by our limited understanding of the connectivity between breeding and wintering ranges in the Rustic Bunting. Lightweight, light-level geolocators and stable isotope analysis provide new tools for studying such questions, but to date they have not been used to any larger degree on migratory songbirds in Asia (Yong et al. 2015). Knowledge about the migration routes and the wintering areas of the Rustic Bunting will be vital for prioritizing sites for new monitoring schemes in the Far East and for planning international conservation efforts.

\section{Supplementary Material}

To view supplementary material for this article, please visit https://oi.org/10.1017/ So959270916000046

\section{Acknowledgements}

Jesper Hornskov, Aleksi Lehikoinen, Åke Lindström, Bo Pettersson, Philip Round, Sergei M. Smirenski, and Terry Townsend kindly responded to personal inquiries and provided population data. We appreciate the comments from two anonymous reviewers and the associate editor. Funding was received from Göran Gustafsson Foundation (to LE), the Finnish Cultural Foundation (to TJ) and the Kempe Foundation (to JMR). 


\section{References}

Achard, F., Molliconi, D., Stibig, H.-J., Aksenov, D., Laestadius, L., Li, Z., Popatov, P. and Yaroshenko, A. (2006) Areas of rapid forest-cover change in boreal Eurasia. For. Ecol. Manage. 237: 322-334.

Alauddin, M. and Quiggin, J. (2008) Agricultural intensification, irrigation and the environment in South Asia: issues and policy options. Ecol. Econ. 65: 111-124.

Amano, T. (2009) Conserving bird species in Japanese farmlands: past achievements and future challenges. Biol. Conserv. 142: 1913-1921.

Averin, A. A., Kalinin, A. J, Malikova, E. I., Osipov, P. E., Rybzova, T. A. and Strelzov, A. N. (2012) Fauna of Bastak Nature Reserve. Blagoveshchensk, Russia: BSPU Press. (In Russian).

Berezovikov, N. N. and Levinskiy, J. P. (2008) New information about the migration of Rustic Bunting Emberiza rustica from East and Southeast Kazakhstan. Russ. Ornithol. J. 416: 694-696. (In Russian).

BirdLife International (2012) Emberiza rustica. The IUCN Red List of Threatened Species. Version 2015.2. (Accessed online 5 July from: www.iucnredlist.org).

BirdLife International (2015a) Species factsheet: Emberiza rustica. (Accessed online 12 July 2015 from: http://www.birdlife.org).

BirdLife International (2015b) European Red List of Birds. Luxembourg: Office for Official Publications of the European Communities.

Bright, J. A., Morris, A. J. and Winspear, R. (2008) A review of indirect effects of pesticides on birds and mitigating landmanagement practices. Sandy, UK: RSPB. (RSPB Research Report No. 28).

Byers, C., Olsson, U. and Curson, J. (2013) Buntings and sparrows. A guide to the buntings and North American sparrows. London, UK: Helm.

Cramp, S. and Perrins, C. M. (1994) Handbook of the birds of Europe, the Middle East, and North Africa: The birds of the Western Palearctic. Volume IX: Buntings and New World warblers. Oxford, UK: Oxford University Press.

Dale, S. and Hansen, K. (2013) Population decline in the Rustic Bunting Emberiza rustica in Norway. Ornis Fenn. 90: 193-202.
Flannigan, M., Stocks, B. Turetsky, M. and Wotton, M. (2009) Impacts of climate change on fire activity and fire management in the circumboreal forest. Global Change Biol. 15: 549-56o.

Fujioka, M., Lee, S. D., Kurechi, M. and Yoshida, H. (2010) Bird use of rice fields in Korea and Japan. Waterbirds 33: 8-29.

Gilbert, M., Sokha, C., Joyner, P. H., Thomson, R. L. and Poole, C. (2012) Characterizing the trade of wild birds for merit release in Phnom Penh, Cambodia and associated risks to health and ecology. Biol. Conserv. 153: 10-16.

Goldammer, J. G. and Furyaev, V. V. (1996) Fire in ecosystems of boreal Eurasia. Ecological impacts and links to the global system. Pp. I-2O in J. G. Goldammer and V. V. Furyaev, eds. Fire in ecosystems of boreal Eurasia. Dordrecht, The Netherlands: Kluwer Academic Publishers. (Forestry Science 48). Green, M. and Lindström, A. (2015a) Övervakning av fäglarnas populationsutveckling. Årsrapport för 2014. Rapport, Biologiska institutionen, Lunds Universitet. (In Swedish).

Green, M. and Lindström, A. (2015b) Svensk fågeltaxering 2014. SOF-Birdlife 2015. Fågelåret 2014. Halmstad. (In Swedish).

Hansen, K. (2015) Vierspuroprosjektet 2015 status 2015. Oppdragsrapport for Fylkesmannen i Hedmark, Oslo, August 2015. (In Norwegian).

Heim, W., Smirenski, S. M., Siegmund, A. and Eidam, F. (2012) Results of an autumnal bird ringing project at Muraviovka Park (Amur Region) in 2011. Avian Ecol. Behav. 21: $27-40$.

Heim, W. and Smirenski, S. M. (2013) The Amur Bird Project at Muraviovka Park in Far East Russia. Birding ASIA 19: 31-33.

Iijima, K. 1973. A comparative study on the wintering ecology of four species of Emberiza in the basin of Chikuma River. J. Yamashina Inst. Ornithol. 7: 179-201. (In Japanese with English summary).

Jiang, Y.-L., Gao, W., Lei, F.-M., Wan, D.-M., Zhao, J. and Wang, H.-T. (2008) Nesting biology and population dynamics of Jankowski's Bunting Emberiza jankowskii in Western Jilin, China. Bird Conserv. Internatn. 18: $153-163$. 
Kamp, J., Oppel, S., Ananin, A. A., Durnev, Y. A., Gashev, S. N., Hölzel, N., Mischenko, A. L., Pessa, J., Smirenski, S. M, Strelnikov, A. G., Timonen, S., Wolanska, K. and Chan, S. (2015) Global population collapse in a superabundant migratory bird and illegal trapping in China. Conserv. Biol. 29: 1684-1694.

Kretchmar, E. A. (2000) The Rustic Bunting Emberiza rustica on the mid-Anadyr River. Russ. J. Ornithol. 123: 14-24.

Laaksonen, T. and Lehikoinen, A. (2013) Population trends in boreal birds: continuing declines in agricultural, northern, and long-distance migrant species. Biol. Conserv. 168: 99-107.

Long, H., Liu, Y., Wu, X. and Dong, G. (2009) Spatio-temporal patterns of farmland and rural settlements in $\mathrm{Su}-\mathrm{Xi}$-Chang region: implications for building a countryside in coastal China. Land Use Policy 26: 322-333.

Maeda, T. (1973) Comparative ecology of Emberizids wintering in central Honshu especially of Emberiza rustica and E. cioides. J. Yamashina Inst. Ornithol. 7: 139-159. (In Japanese with English summary).

Maeda, T. (2001) Patterns of bird abundance and habitat use in rice fields of the Kanto Plain, central Japan. Ecol. Res. 16: 569-585.

Metla (2015) Impacts of forest management on waters. State of Finland's Forests 2102. (Accessed online 11 July 2015 from: http:// www.metla.fi/metinfo/sustainability/ c5-impacts-of-forest.htm).

Öhrn, B. (1963) Videsparven, en sen invandrare från öster. Pp. 113-131 in V. Olsson, ed. Barrskogens fåglar. Stockholm: Geber. (In Swedish).

Pannekoek, J. and van Strien, A. J. (2013) TRIM 3 manual. TRends and Indices for Monitoring data. Research Paper No. O102. Voorburg, The Netherlands: Statistics Netherlands.

Pulliainen, E. and Saari, L. (1989) Breeding biology of Rustic Buntings Emberiza rustica in eastern Finnish Lapland. Ornis Fenn. 66: 161-165.

Rogacheva, H. (1992) The birds of Central Siberia. Husum, Germany: Husum Druckund Verlagsgesellschaft.

Round, P. D. and Gardner, D. (2008) The birds of the Bangkok area. Bangkok: White Lotus.

Sanderson, F. J., Donald, P. F., Pain, D. J., Burfield, I. J. and van Bommel, F. P. J. (2006)
Long-term population declines in AfroPalearctic migrant birds. Biol. Conserv. 131: 93-105.

Schäfer, N., Meffert, P. and Heim, W. (in prep.) Habitat use of Passerines at a stop-over site in Far East Russia.

Shi, Y., Xiao, J., Shen, Y. and Yamaguchi, Y. (2012) Quantifying the spatial differences of landscape change in the Hai River Basin, China, in the 1990s. Int. J. Remote Sens. 33: 4482-4501.

Skogsstyrelsen (2014) Swedish statistical yearbook of forestry 2014. (Accessed online 11 July 2015 from: http://www.skogsstyrelsen. se/Global/myndigheten/Statistik/ Skogsstatistisk \% 20\% $\mathrm{C}_{3} \% \mathrm{~A}_{5} \mathrm{rsbok} / \mathrm{or}_{1} \%$ 2oHela \% 202014\% 20-\% 2OEntire\% 202014/ Skogsstatistiska \% 20\% $\mathrm{C}_{3} \% \mathrm{~A}_{5}$ rsboken $\%$ 202014\% 2O(hela).pdf)

Soja, A. J., Tchebakova, N. M., French, N. H. F., Flannigan, M. D., Shugart, H. H., Stocks, B. J., Sukhinin, A. I., Parfenova, E. I., Chapin, F. S. III and Stackhouse, P. W. Jr. (2007) Climate-induced boreal forest change: predictions versus current observations. Global and Planetary Change 56: 274-296.

Symes, A. (2015) Rustic Bunting (Emberiza rustica) - uplist from Least Concern to Near Threatened or Vulnerable? BirdLife's globally threatened bird forum. (Accessed online 8 July 2015 from: http://www. birdlife.org/globally-threatened-birdforums/).

Tamada, K., Tomizawa, M., Umeki, M. and Takada, M. (2014) Population trends of grassland birds in Hokkaido, focusing on the drastic decline in the Yellow-breasted Bunting. Ornithol. Sci. 13: 29-40.

Townsend, T. (2015) Beijing's wild bird markets. (Accessed online 10 July 2015 from: http:// birdingbeijing.com/2013/11/13/beijingswild-bird-markets/).

Valchuk, O., Yuasa, S. and Morosova, E. (2005) Migration of Rustic Bunting Emberiza rustica at the eastern edge of Asia. Alauda 73:323.

Valkama, J., Vepsäläinen, V. and Lehikoinen, A. (2011) The third Finnish breeding bird atlas. Helsinki, Finland: Finnish Museum of Natural History and Ministry of Environment. (Accessed online 18 Sep 2015 from: http://atlas3.lintuatlas.fi/english). 
Vickery, J. A., Ewing, S. R., Smith, K. W., Pain, D. J., Bairlain, F., Skorpilova, J. and Gregory, R. D. (2014) The decline of Afro-Palearctic migrants and an assessment of potential causes. Ibis 156: 1-22.

Wu, J.- X., Cheng, X., Xiao, H.-S., Wang, H., Yamg, L.-Z-. and Ellis, A. C. (2009) Agricultural landscape change in China's Yangtze Delta, 1942-2002: a case study. Agric. Ecosyst. Environ. 129: 523-533.
Yong, D. L., Liu, Y., Low, B. W., Española, C. P., Choi, C.-Y. and Kawakami, K. (2015) Migratory songbirds in the East Asian-Australasian Flyway: a review from a conservation perspective. Bird Conserv. Internatn. 25: 1-37.

Yoo, S. H., Lee, K. S., Kim, J. H. and Park, C. H. (2011) Wintering avifauna and community changes in response to agricultural intensification in Cheorwon, Korea. J. Korean Nature 4: 287-292.

\section{LARS EDENIUS*, ADRIAAN DE JONG, JEAN-MICHEL ROBERGE}

Department of Wildife, Fish, and Environmental Studies, Swedish University of Agricultural Sciences, SE-90183 Umeå, Sweden.

\section{CHANG-YONG CHOI}

Department of Forest Sciences, Seoul National University, Seoul 151-921, Republic of Korea.

\section{WIELAND HEIM}

Amur Bird Project, Roseggerstraße 14, 14471 Potsdam, Germany, and Animal Ecology,

University of Potsdam, Maulbeerallee 1, 14469 Potsdam, Germany.

TUOMO JAAKKONEN

University of Oulu, Department of Biology, P O. Box 300o, FI-goo14 Oulu, Finland.

\section{KIYOAKI OZAKI}

Division of Avian Conservation, Bird Migration Research Center, Yamashina Institute for Ornithology, 115 Konoyama, Abiko 270-1145, Japan.

*Author for correspondence; e-mail: lars.edenius@slu.se

Received 22 September 2015; revision accepted I February 2016; Published online 18 April 2016 